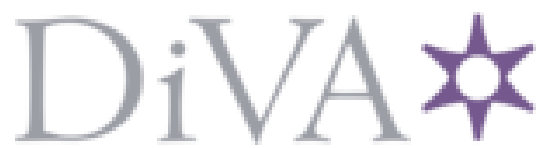

http://www.diva-portal.org

\title{
Postprint
}

This is the accepted version of a paper presented at $P D C$ '2O: Proceedings of the 16th Participatory Design Conference 2020 - Participation(s) Otherwise.

Citation for the original published paper:

Lindström, K., Ståhl, Å. (2020)

Un/Making in the Aftermath of Design

In: Chiara Del Gaudio, Leonardo Parra-Agudelo, Rachel Clarke, Joanna Saad-Sulonen, Andrea Botero, Felipe César Londoño, Paula Escandón (ed.), PDC '20: Proceedings of the 16th Participatory Design Conference 2020 - Participation(s) Otherwise (pp. 12-21). New York, NY: Association for Computing Machinery (ACM) ACM International Conference Proceeding Series (ICPS)

https://doi.org/10.1145/3385010.3385012

N.B. When citing this work, cite the original published paper.

Permanent link to this version:

http://urn.kb.se/resolve?urn=urn:nbn:se:Inu:diva-96942 


\section{Un/Making in the Aftermath of Design}

\author{
Kristina Lindström \\ Malmö University, K3 \\ Malmö, Sweden \\ kristina.lindstrom@mau.se
}

\author{
Åsa Ståhl \\ Linnaeus University \\ Växjö, Sweden \\ asa.stahl@lnu.se
}

\begin{abstract}
This paper takes as its starting point the fact that we live in the aftermath of previous making and design. For participatory design to adequately answer to this aftermath, we suggest building on a combination of participatory and speculative design approaches in everyday life settings and exploring the practice of un/making matters. The paper draws on two cases where participants have been invited to engage with recent scientific findings and practices - one where they explore the practice of un/making plastic waste through composting, and one on un/making polluted soil through plants that can accumulate metals. By not primarily aiming at feeding into new iterations of a design process, there is an openness for speculating beyond the given systems, and to bring into question imaginaries of constant progress, which have been part of generating these lingering matters.
\end{abstract}

\section{Author Keywords}

Unmaking; aftermath; speculative design; plastics; soil.

\section{CSS Concepts}

- Participatory design

\section{- Social and professional topics -> Sustainability \\ INTRODUCTION}

Design as a discipline is future oriented. More specifically design is concerned with ".. changing existing situations into preferred ones" [35]. Within participatory design a central objective has been to allow those with things at stake to be part of the process of deciding what is preferred or not. Participatory design has in other words been concerned with democratizing design through enabling participation in the design process.

In recent years, it has however become more and more recognized that design does not only matter during use-time, but also in the aftermath of use, when things are replaced, left behind and becoming waste. The aftermath of design is

(C) $\{$ Owner/Lindström and Ståhl $\}\{2020\}$. This is the author's version of the work. It is posted here for your personal use. Not for redistribution. The definitive Version of Record was published in

PDC '20: Vol. 1, June 15-20, 2020, Manizales, Colombia

(C) 2020 Copyright is held by the owner/author(s). Publication rights licensed to ACM. ACM ISBN 978-1-4503-7700-3/20/06 ..\$15.00 DOI: $10.1145 / 3385010.3385012$

\footnotetext{
${ }^{1}$ Phytoremediation is a way of using plants to extract metals from soil and thereby clean the soil. Some plants have the capacity to accumulate particular metals.
}

however characterized by multiple uncertainties, for example in terms of who is affected and how, as well as who should care for these matters and how.

In this paper we will propose a shift in focus, from attending to matters and controversies that emerge in relation to new and emerging technologies, which often has been the case within participatory design, to matters that emerge in the aftermath of design. In that sense we propose a shift from inviting for participation in the making of the new through making new things and services, to un/making harmful relationships that have emerged in the aftermath of previous makings.

The practice of un/making will be explored through two projects, that are situated within an emerging body of work that combines participatory design with speculative design $[3,15,17,32]$. While these two projects have slightly different set ups, they both invite to engage with new and still speculative proposals for how to engage with the aftermath of previous designs. More specifically, the projects engage with the possibility of un/making plastic waste through composting and un/making polluted soil through phytoremediation ${ }^{1}$. Rather than situating speculations in galleries, which often is the case with speculative design, the two projects invite actors to bring these still speculative practices of un/making into their own everyday lives. Through, for example, prototypes and guidelines the un/making of the aftermath is made doable, or at least almost doable. The aim here is not to gather knowledge and insight that can be fed into the next iteration of a design process. Rather than being an inquiry for design, these explorations of un/making can, in line with other attempts to combine speculative and participatory design processes [6,37], be seen as an inquiry through design, that might teach us something about the condition of design. Or, more specifically, that can teach us something about the condition of the aftermath of design.

\section{UN/MAKING MATTERS}

Encountering reports and news articles on microplastics falling with the snow in the Arctic [1], plastic particles found in sea salt [42] and new homes and gardens built on soil with asbestos from former eternite industries [36] we are reminded that the past matters. Or, put in a slightly different 
way, we are reminded that we live in the aftermath [19] of industrialised design often driven by progressivist and anthropocentric imaginaries. Design has in other words not only participated in making particular ways of living possible, it has also participated in generating harm beyond use-time for both humans and non-humans. Design can in that sense be understood as both creative and destructive $[10,11,39,40]$. As pointed out by Tonkinwise [39] the main focus within design has however been on what design makes, rather than what it unmakes and leaves behind to become waste.

Responding to harm that has been generated in the aftermath of progressivist and anthropocentric ways of thinking and doing that has been part of design, we can today witness a variety of attempts to rework and rethink these practices. We are invited to imagine what it would mean to undesign [4], unmake capitalism [8,41], and even ungarden [20]. Through the use of the prefix un it is suggested that the proper response to the challenges that we are facing, might not be more design, making new things and leaving the old behind, but that we might "... achieve a better result by untying a knot or undoing something" [29]. While these different calls for undesigning and unmaking stress the need of "undoing something", they should not only be understood as a move away from something, but simultaneously a move towards something. Unmaking, undesigning or undoing can thereby be understood as, "... processes that are deliberatively activated in order to "make space" (temporally, spatially, materially, and/or symbolically) for radical alternatives that are incompatible with dominant modern capitalist configurations [8]".

In order to rework how design is practiced and imagined we have set up the Un/Making Studio ${ }^{2}$. Our attempts have involved trying to unmake often taken for granted practices and imaginaries within design in order to "make space" for alternative ways of figuring design. More specifically this has involved "making space" for a design practice that draws on an understanding of design as both creative and destructive. To further explore this double movement between making and unmaking, we have carried out a series of projects that approach un/making in slightly different ways. One of our first projects engaged with the already ongoing work of banning, and in other ways getting rid of, plastic straws. In the project called Un/Making the Plastic Straw we designed and exhibited a series of prototypes that offered different alternatives to plastic straws, and addressed different themes of disposability. The designs did not propose something completely new, but acted as a form of revival [34] of alternatives that previously had been deemed unpreferable, in combination with already emerging ways of un/making the plastic straw. In parallel to un/making the plastic straw through offering alternatives, we also invited to a so called 'plogging session' which is a term for going jogging while picking plastic waste. We did not jog, but collected a variety of plastic items, including plastic straws that had already been made, used and left behind generating an aftermath that will last and have affects, even if we would stop producing and using plastic straws from now on.

In Un/Making the Plastic Straw we primarily approached un/making as a practice of hindering [39] unsustainable practices and products by offering alternatives in the form of prototypes. Through the "plogging" session the un/making was also directed towards harmful relationships that have emerged in the aftermath of previous design. In this paper we will focus on the latter approach to un/making.

\section{PARTICIPATION AND SPECULATION IN AND THROUGH DESIGN}

In our work to craft invitations to un/make matters that have emerged in the aftermath we draw on approaches and perspectives from participatory design, speculative design and an emerging body of work that combines these two fields (see for example the following exploratory papers, workshops and situated actions from the two most recent participatory design conferences $[3,15,17,32,33])$. This paper will not provide a comprehensive map of this emerging body of work. Instead this section aims to sketch out some critique that has been raised towards participatory and speculative design and to situate the approach used in this paper in relation to other attempts to combine participatory and speculative design.

Participation has been sought out in many design processes as a way of including future users and those who will be affected by the future design. Within the participatory design community there is an articulate quest to empower the marginal. Historically, Scandinavian participatory design has for example been liaised with labour unions to prevent deskilling of workers when new technologies were introduced. Speculative design shares this objective to engage collectives and publics in issues related to new and emerging technologies. However, the engagements within speculative design rarely involve participation in the design process, which is central within participatory design. In other words, participatory design is situated in lived experiences while speculative design often exhibits evocative objects and scenarios, designed by designers. Compared to participatory design, objects and services designed within speculative design are rarely meant to be used. Instead the main objective is to challenge the status quo and spark debate [22], through design.

What constitutes a generative or fruitful speculation through design, is however highly contested. Dunne and Raby [7] argue for designing speculative objects and things that are scientifically plausible, and that can be placed somewhere in between the probable and the plausible. Tonkinwise [38] questions this assumption, that a generative speculation or

\footnotetext{
${ }^{2}$ www.unmakingstudio.se
} 
preferable futures, are to be located in between the probable and the plausible. More likely, he suggests, it might be found beyond the possible, in the impossible. Galloway [13] also questions the assumption that a good speculation, or science fiction, should be scientifically plausible. Drawing on feminist science fiction and fantasy, she suggests that the important thing is to move something or someone.

An overarching criticism in relation to speculative design is how it manages to engage audiences. While there is much focus on generating debate, "Speculative projects typically appear as static images or artifacts on display, prioritizing the aesthetic vision rather than enabling a collaborative process of imagination" [15] In addition, the audience is often expected to imagine and narrate the world around the exhibited object, which is a demanding task. As pointed out by Malpass [28] and Galloway and Caudwell [14] there is often a need for additional contextual and narrative element, beyond the designed object.

Others have critiqued speculative design for being produced from privileged positions, which undermines the intention of critiquing power structures (see for example Prado and Oliviera [31]). Furthermore, it rarely manages to engage with or involve those who might be most affected by the implications of issues that the project works with [15], which has been, and still is, at the core of participatory design.

While speculative design has been criticised for how it manages to engage its audiences, how and to whom these objects can become relevant, participatory design has been criticised for being limited to solutions that are possible within the systems it is working in. Responding to these concerns, scholars within participatory design have started to combine speculative and participatory design approaches.

Gerber [15] for example, states that including more speculative elements in participatory design makes space to imagine possibilities beyond current systems and other forms of limitations. Similarly, Tironi [37], suggests that working with speculative prototypes within participatory design allows for moving beyond predefined solutions, and to allow for friction and difference to emerge, which in turn can allow for a process of renegotiating the conditions of participation. The main concern here is in other words, not to include the excluded, which often is the ambition within participatory design. Rather, the goal should be to open up possibilities for the 'excluded' to "emancipate themselves from the conditions imposed by others" [37]. Tironi suggests that speculative prototyping or interventions have a central role in creating such conditions, since it goes beyond the idea of consensus and recognises frictions and disruptions as a mode of exploration.

In line with DiSalvo's [6] articulation of speculative interventions these approaches become a mode of inquiry through design, that does not necessarily feed into the making of a new design solution. In other words, these speculative interventions and prototypes are not to be understood as a test of a beta-version that can then be refined in the next iteration [37]. They are not done for design. Instead, speculative interventions and prototypes has the potential to tell us something about the conditions of design and to articulate issues related to those conditions [6,37].

Our methodological assemblage [23], bares similarities with speculative prototypes [37] and speculative interventions [6] in that it suggests that speculations take place through material engagements situated in specific contexts, rather than in a gallery space. More specifically our methodological assemblage, consists of invitations to un/make different matters that have emerged in the aftermath of design. The different proposals for un/making could be experienced, tried out and explored in their everyday lives. In other words, they were along the lines of speculative intervention [6] doable, or at least almost doable. So, whereas Dunne and Raby [7] consider their speculative designs to be props in an imaginary future or alternative present, this work recognizes that the events, prototypes and designs are of the world and in the world, full of entanglements. In that sense it becomes what DiSalvo [6] describes as a mode of inquiry that primarily is concerned with the lived, rather than the designed.

However, rather than working with concerns related to the use of new and emerging technologies, which often is the case within both participatory design and speculative design, our work invites to un/making matters that are emerging in the aftermath of previous design. Those affected are in other words not primarily users of new things, but those affected also beyond use-time. And, rather than inviting to participate in the making of new things, services and systems, the invitation opens up for practices of un/making.

In the following section we will discuss the condition of the aftermath and the possibilities of un/making matters in the aftermath of design through combining participatory and speculative design approaches.

This will be done through two projects called Composting Plastics and Un/Making Soil Communities. Both cases engage with recent scientific findings and proposals for how to un/make the aftermath of design. The first one engages with plastic waste, or more specifically the possibility to compost plastics in a domestic setting. The second project invites to care for polluted soil through phytoremediation. While the specific proposals for un/making could be considered scientifically plausible, they were also rather spectacular and had managed to move people. As we will discuss in the following sections both of these proposals had prior to our engagements managed to spark curiosity, worry and debate. To further cultivate the already ongoing speculations related to these matters and how to un/make them we could have used a range of different methods. We chose to craft invitations to bring these rather spectacular, fantastic and evocative proposals into mundane everyday contexts, such as kitchens and gardens, and thereby situating 
the participatory design activities with speculative elements in everyday life.

\section{COMPOSTING PLASTICS}

Concern has been raised by many for quite some time around the dispersal and distribution of plastic waste and how it has uncertain as well as unintended effects (see for example $[5,12,24])$. Although the advantages of plastics are many, such as its capacity to be shaped into many forms and that it is lightweight, the afterlife of plastics is long and unpredictable. When a scientific finding [43] stated that the afterlives of some plastics could be cared for by common mealworms that has been shown to be able to biodegrade Styrofoam, it received significant attention across various news and social media outlets $[9,16,18]$. This sped-up process of taking care of the aftermath inspired hope.

For participatory design matters such as plastic waste poses particular challenges. It has been shown that, whether one recognises oneself as affected or not, we are all affected in more or less obvious or (in)direct ways by plastic waste. As we have articulated in a previous paper, this suggests that stakes and stakeholders are not a priori given. The challenge thus becomes to craft invitations that allow for the becoming of stakes and stakeholders [25].

To invite for a combination of speculation and participation in the un/making of plastic waste, we crafted an invitation to compost plastics in a domestic setting using the newly found capacity of mealworms. The actual process involved two gatherings in the basement of an apartment building in Copenhagen with approximately two weeks in-between. About 20 people on both the Swedish and the Danish side of the Oresund responded to our invitation by turning up, including colleagues, students and friends. The invitation did thus not reach far beyond our own and our collaborators' immediate networks. During the first meeting the participants assembled a composting kit, that consisted of a glass jar, a metal net and common mealworms. During the event we also served take away food in Styrofoam containers, which the participants could later use to feed the worms. This was done in order to introduce the matter into the gathering. The participants then brought the composting kits and a booklet for self-documentation with them home. A couple of weeks later we gathered again to share the processes.

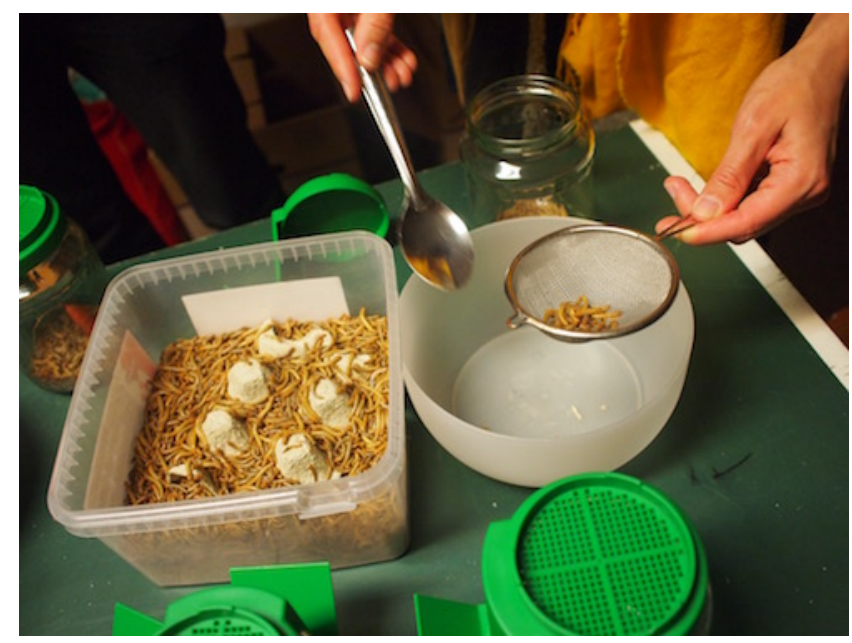

Figure 1. Participants assembling worms and Styrofoam in a glass jar to bring home.

Through the prototypes, our speculative proposal to compost Styrofoam in a domestic setting was, in line with speculative prototypes and interventions, made doable or almost doable. When we gathered two weeks later, the participants shared a range of experiences of the composting they had engaged with in their daily lives. Some experienced the composting as messy and disgusting, leading them to move the compost outdoors. Some experienced the process as too demanding and risky which made them quit the experiment. Others developed a more pet like relationship to the worms and rebuilt the compost to give them more space and things to play with.

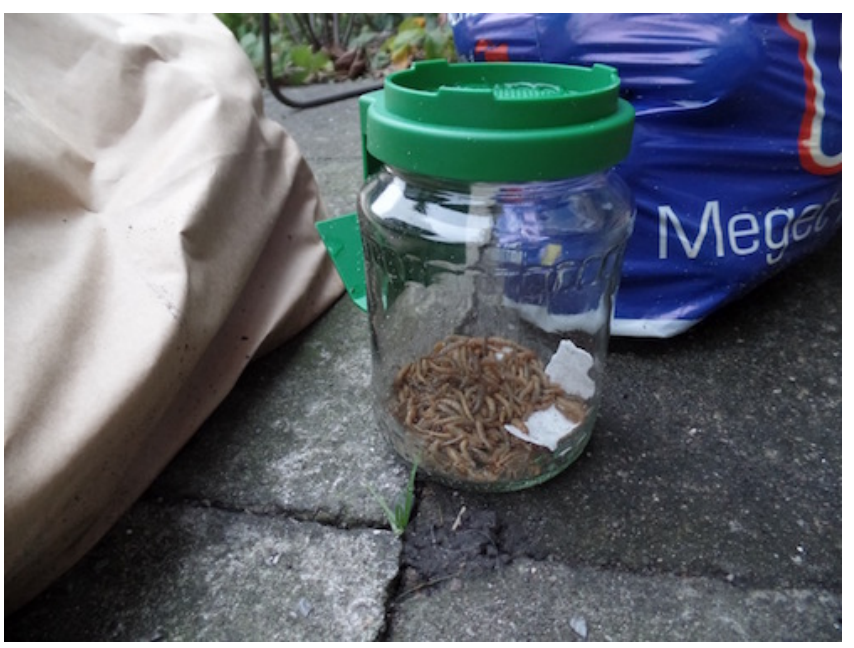

Figure 2. Compost that has been moved outdoors. 


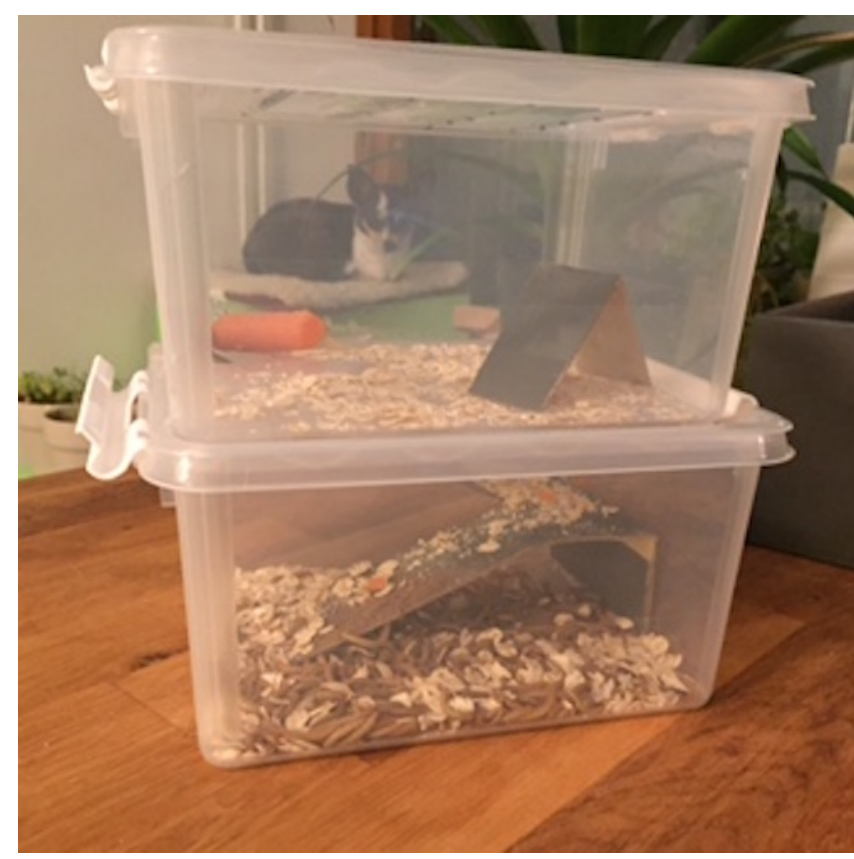

Figure 3. Rebuilt space for worms giving them more space and things to play with.

The compost had, in line with Dunne and Raby [7], become a prop in multiple unfolding stories. The unfolding narratives were however based on real life experiences, situated in different contexts full of entanglements, rather than in a gallery space.

While it was possible to try out the composting at home, there were several uncertainties and missing parts such as infrastructures that would be needed for this to take place on a larger scale and beyond the two weeks of the engagement. In other words, the proposal was predominantly doable on an individual level, in small scale and during a short timeframe.

While the prototype that we had offered did not allow for composting plastics in a collective manner, that was institutionalised and implemented on a larger scale, these aspects became a matter of speculation. In other words, the missing parts opened opportunities for imagining how things could be otherwise. The participants shared practices from around the world on how one can handle waste. Yet others had been preoccupied with what would happen to the worms when they were no longer in a larvae-state, but turned into bugs. They had started imagining setting up a worm-farm to have a constant supply of common mealworms. Another possibility that was mentioned was eating them or feeding them to other animals before the worms transformed from one state to another.

Overall the proposal to un/make plastic waste through composting did not emerge as a simple fix of the problem. Instead it emerged as a proposal with multiple uncertainties and missing pieces. Based on observations of tiny white pieces of Styrofoam mixed with faeces and other material at the bottom of the composting kit, it was questioned whether it would be safe to use them as fertilizers for urban gardening. The observations indicated that the worms were spilling crumbles of the Styrofoam when they were munching on it. Overall, there were many concerns regarding systems and circularity. For example, when it was imagined that the slow and, in many ways, inefficient process of composting plastics could be sped up by bioengineering the worms, there were others who hesitated and pointed out that already now it could be a problem if common mealworms invaded households and started to damage plastic items. What would it be like if the worms were enhanced in their capacity to biodegrade plastics? What if they escaped and went munching on cables and containers of various sorts?

Several participants also questioned the proposal to un/make plastics at all. Rather than composting, they suggested that the plastics should be recycled or reused. It was also suggested that there were more appropriate ways to un/make it, for example, through stop using it and use renewable materials. Throughout the process several participants also brought up ethical questions and the well-being of the worms as they were fed plastics, as well as the well-being of humans and other species such as birds who might feed on the worms.

The proposal enacted through the prototype did in that sense not result in knowledge ready to be used in the next iteration of a design process. Instead, the prototype became part of generating multiple and at times conflicting speculations on how to un/make plastic waste. Through composting we unmade some plastic waste. We also unmade the idea of this proposal as a simple fix.

\section{UN/MAKING SOIL COMMUNITIES}

The second project started off in an area in southern Sweden known for its glass production, which was an important industry in this area for about a century. Throughout the 1900 's designers connected to the industry put not only the region, but also the whole country on the map for its aesthetically pleasing and avantgarde glassware. Although most production has now moved to other parts of the world, there is an aftermath of the former production in the soil in this very area. For example, arsenic, lead, copper, cadmium and other metals that were used in the production, often in order to achieve a particular aesthetic expression, can still be found in the soil.

While the issue of polluted soil in the aftermath of glass production is well known in the area, it is not obvious how to take care of it, or who should do it. There are also multiple uncertainties in terms of who is affected by it, when and how. Some actors propose to ship the most polluted matters to landfills in order to get it out of the way. Attention has also been drawn to scientific findings showing that certain plants can accumulate certain metals: phytoremediation [21]. In this very region there is a research group who have engaged with the polluted soil around the former glass industry. They are working on getting to know the soil and former dumps as well as exploring the possibility of using plants to take care of the pollution. Part of this engagement has also led to the construction of a phytoremediation park in a former apple 
orchard $^{3}$. The park is a collaboration with a newly formed company that has also, in the pursuit of providing experiences for tourists, built a new furnace next to the old ones. The park is meant to spark debate and show what plants could be used for phytoremediation in relation to the metals previously used in glass production. The park is in itself a speculation, since the polluted soil that was there has been moved to landfills. The municipality did not give permission to do a full-scale experiment.

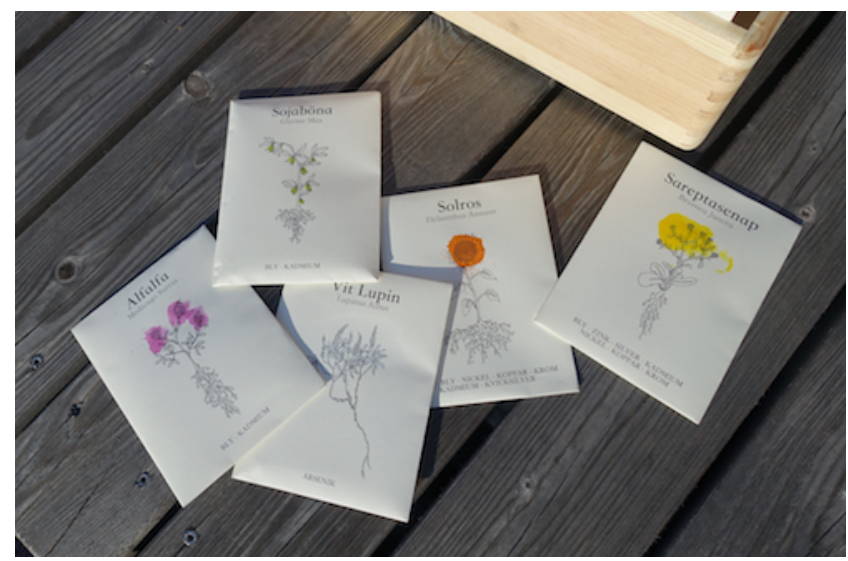

Figure 4. Seed bags that were distributed during our visits.

To further explore this still speculative way of un/making the polluted soil in the area together with people living in the vicinity, we crafted an invitation. The invitation asked people to pick a place that they thought was in need of care. Furthermore, the participants were asked to pick one or several seeds that we had brought. The seeds ${ }^{4}$ were chosen because of their capacity to accumulate particular metals from the soil. At the same time, they have other capacities, such as growing into plant protein for humans as well as more-than-humans.

This invitation has been enacted in several versions, iterations and rearticulations [26]. Contacts and relationships within the area has been developed over time and long before this project started. About fifteen years ago we designed an exhibition on the topic of glass objects and gifts. We have worked with a design archive in the area and during the summer just before the project started we hosted a $\mathrm{PhD}$ summer school in the area. These engagements have played a crucial role in setting up the project and getting in contact with people living in the area, people working with glass as well as other researchers who work on similar topics but from a natural science perspective. For example, one person working in the newly rejuvenated glass production, that we got in contact with during the $\mathrm{PhD}$ summer school, helped in circulating a flyer with an invitation to a first meeting.

\section{3}

https://nu.se/en/research/searchresearch/forskningsprojekt/ project-phytoremediation-park-in-kingdom-of-glass/
The first meetings on autumn evenings took place next to the new furnace and phytoremediation park, close-by the older glass production. The response was as could be expected: not many came, but those who did so were already curious and interested. They had, for example, seen the flyer in the local grocery store or in the local Facebook group. Others we got in touch with through visiting the local antique shop, specialized in designed glass objects from that particular area. Yet others came by because they also had other things to do nearby.

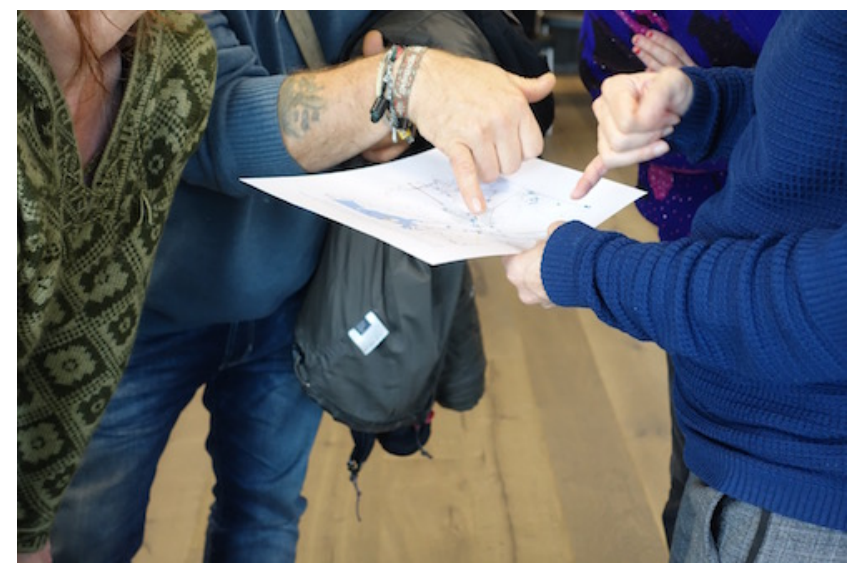

Figure 5. Participants locating polluted areas on a map.

During the first visits, that took place in the autumn, most time was spent on locating and visiting places in need of care and making plans for the coming planting season. To support this process, we had brought a local official map, where polluted sites in the area are marked. Despite the season, we also distributed the bespoke seed bags to those who were interested in planting some seeds. A few participants brought us to places that they cared for and were curious about, such as a dump in the forest that had been closed during the 1970s, a former railway station turned into a leisure area and a garden. As we visited some of these locations we could notice obvious traces from previous glass industry, such as dumps of glass blobs of various kinds as well as glass as filling material in both public and private areas. In gardens we also observed how particularly chosen glass blobs were used as decorations.

4 The seeds included Sunflower, Alfalfa, White Lupin, Indian Mustard and Soy Beans. 


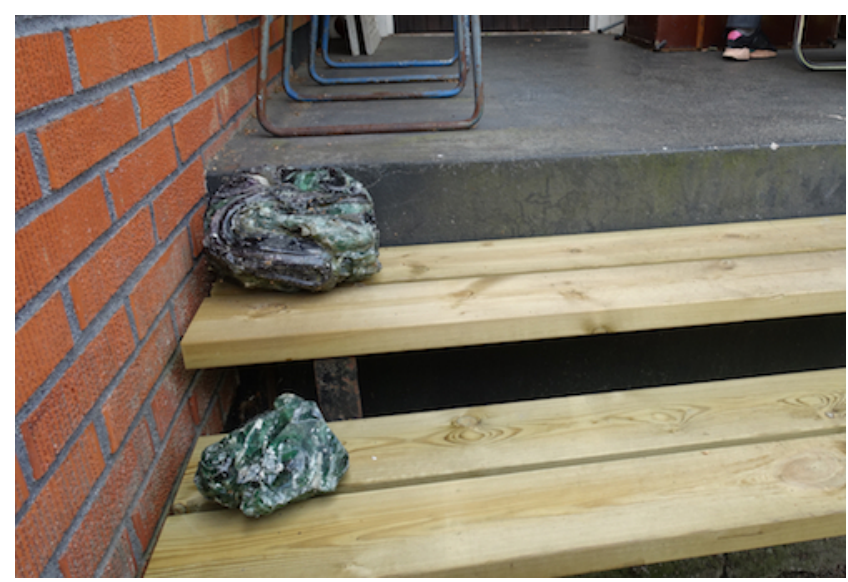

Figure 6. Leftover materials from glass production used as decoration in a private garden.

Several participants also engaged in conversations regarding past ways of living in this area. For example, in meetings with us and amongst participants there have been both historicizing and perspectivizing on waste-handling: a way of informing oneself and reflecting beyond the given moment. One participant told us about burning diapers in the garden when her children were young and plastic diapers were new. Another one shivered at the thought of the practice of dumping things in the forest, before strict waste-handling was put in place. Yet others asked themselves about the practice of playing in the dumps where glass factories had piled up mesmerizing and attractive glass blobs. These were not speculations into the future, as most speculations are, but into the past. Or, rather, they were questions to former selves and societies about how practices can change over time in relation to knowledge and infrastructures of waste-handling. These were thus stories of past practices and ways of living that had participated in the making of the aftermath that we had invited to un/make through phytoremediation.

Meanwhile the participants together with us started to discuss this proposal, to un/make through phytoremediation, and to make plans for where to plant seeds, several participants also voiced their concerns with this proposal. How to mark the area, to whom, while the plants were growing? Would birds be in danger if they ate seeds from the sunflower? Are any of these plants invasive? What wastehandling-infrastructure can handle plants that have accumulated metals? In some discussions it has been asked where this would make most sense: in one's own garden or can plants phytoremediate larger areas and be a viable alternative to, for example, putting polluted soil in landfills?

In parallel to these future-oriented what if questions, several participants raised questions concerning what is in the now. For example, during walks together with the participants we were asked: is the soil in my garden polluted, is it ok to eat greens already growing in one's garden, are they also accumulating heavy metals? Our own knowledge was too limited and we could not answer those questions. However, we did start to plan for how to involve and collaborate with those who would be better equipped at answering these questions properly.

As a response to our limited knowledge, we rearticulated the invitation and reached out to a research group that we had previously been in touch with. In collaboration with doctoral students in environmental science we were guided in how to make instructions for how to take soil samples. We distributed soil sample kits, with a device and guide. The soil samples were then collected and included in an exhibition in an art gallery in the region. An event of soil scanning was announced, to which two of the doctoral students in environmental science brought a soil scanning device. The results that the soil scanner showed were filed and compared to the threshold limit values that a national agency has published. There were however discussions on the reliability of the results, which is common within citizen science. In particular, it was raised that there might be differences since the samples were taken by different people under different circumstances with only a written guide to lean on.

There were several potentials with the invitation for a soil scanning session in the exhibition, but also limitations. For example, the exhibition space was located on a one-hour drive on winter roads from the ones we had been building the strongest relationships to. This seemed to be too distant. To bring it closer to them we decided to also host one in the specific village that we had been visiting the most. Since we had been building up a mutual interest with some in the village, we were invited to join a yearly cleaning day in the spring, when many concerned and engaged citizens gathered to clean up after the winter. The doctoral students in environmental science had brought their exclusive, but portable, gear for continued scanning of soil samples, both pre-planned and collected during the day. The invitation to collect soil samples to be scanned was open in terms of what soil to sample. Everyone did however choose to collect soil from their own gardens or other places where they grow vegetables. Before receiving the results, some participants expressed unease, as if they were about to receive a report on their own health. One person asked, when waiting for the scanning to be done: Am I already dead?, and hesitated to hear the results. To everyone's relief the results for soil in gardens, where participants were already growing or planned to grow plants, showed that the soil was ok. The seeds that we had brought, and that some of the participants chose to bring with them to plant in their gardens, would in other words not do the work of phytoremediation. 


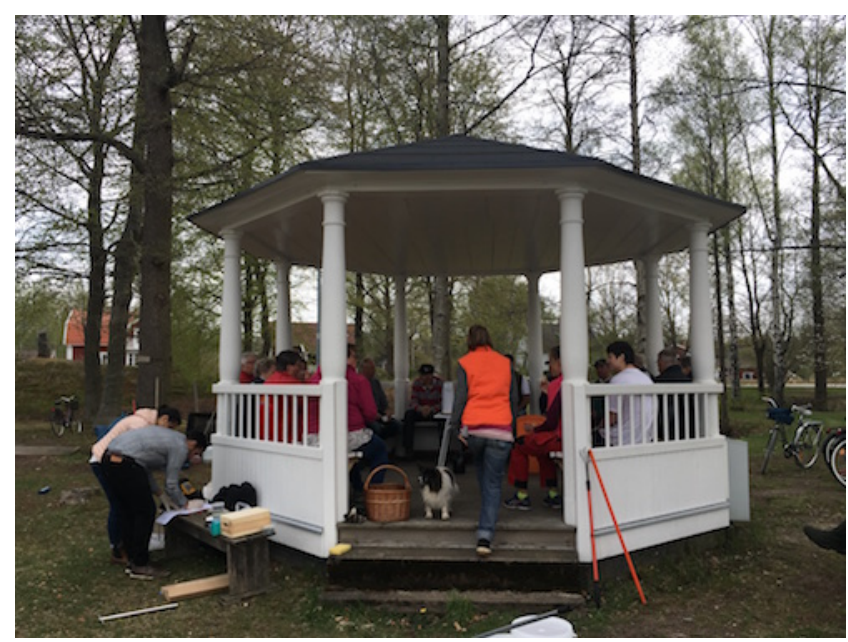

Figure 7. Soil scanning during cleaning day.

As we were about to end the session, one participant suggested that we would take a soil sample a few meters away from the location where we were gathered. He said that we would probably get a different result there, which was also the case. In this particular spot the levels of lead, cobalt, copper and arsenic were way over the threshold. However, no seeds were planted there.

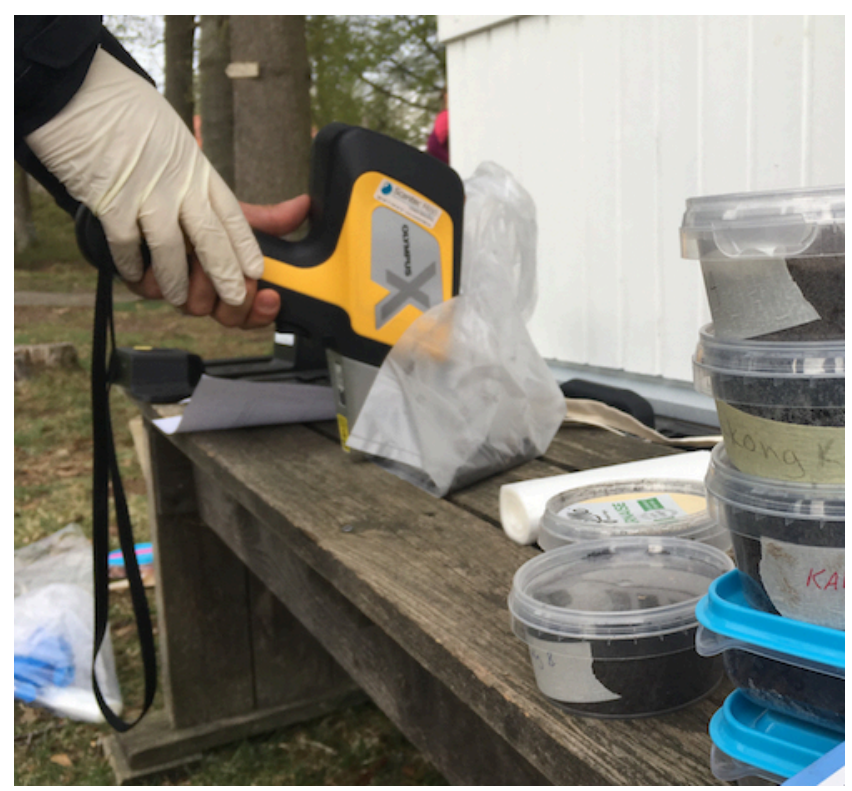

Figure 8. Soil being scanned.

Bringing scientists and locals together in this meeting between different kinds of knowledges and tools, made it possible to approach the un/making in a situated way. The scientists have contacts with other labs and places where necessary expertise might be found in order to elicit information that could shed light on questions raised by the participants. On the other hand, the participants are knowledgeable about historical practices in the area while at the same time have most at stake and most at risk on a daily basis.
In line with composting plastics with the help of common mealworms, the attempts to un/make polluted soil through phytoremediation did not amount to well packaged insights that can be fed into a new iteration of a design process. Instead, the invitation to plant seeds taught us something about the condition of the aftermath and the possibilities of un/making matters in the aftermath of design. It prompted the participants to revisit past ways of living in this area and in specific places and, in particular, how infrastructures, regulations and practices of waste handling have changed. Furthermore, several participants articulated critical questions and risks related to un/making polluted soil through phytoremediation. Rather than embracing this proposal, many participants expressed a desire to know more about the soil they live close to and questioned if it would be safe to grow greens in one's own garden.

\section{CONCLUDING DISCUSSION}

Participatory design has emerged in response to different challenges and matters. Early projects were set in workplaces and focused on issues that were connected to the introduction of new technologies. More recently participatory design has expanded, as Binder et al [2] have outlined, from the workplace to publics. To them this involves a move towards engagements with broader democratic matters, as well as a shift to involve citizens, rather than users.

In this paper the condition we respond to is that of the aftermath of design. Consequently, the issues that we engage with are not primarily those that emerge in use or during use, but rather after use. Those with a stake are thereby not only users, but humans as well as more-than-humans that in different ways are affected by waste produced by and through design.

Furthermore, we suggest that the condition of the aftermath of design requires a shift in the mode of engagement. Responding to matters that have emerged in the aftermath of design, where the creative side of design has been privileged compared to the destructive one, we suggest a turn towards un/making. For participatory design, this involves a shift from inviting to participate in making and creating new technologies, to inviting to participate in un/making. The un/making is however not just an act of turning away from or destroying what has already been made. Neither is it a returning and complete restoration of a past. Instead, un/making involves a deliberate movement between making and unmaking, matters, practices and imaginaries.

Un/Making thereby invites for hesitation regarding the assumption that all kinds of problems require more design or more making [4], and suggests that at times a more proper response might be to unmake in order to "make space" [8] for something else.

\section{Between the doable and the non-doable}

As our account shows, our methodological assemblage of participatory and speculative design approaches opened a kind of collaborative speculation amongst human as well as 
nonhuman participants. However, even more characteristic of these engagements is that the speculations are focused on how we might, intentionally and unintentionally, already participate in the becoming of and ongoing living with specific matters that have emerged in the aftermath of design - as well as how we might want to continue participating or not.

The two cases started off with an invitation to un/make matters that have emerged in the aftermath of design. In line with speculative design both cases draw on new scientific findings and proposals, regarding what, at this moment, can be understood as speculative practices for how to un/make matters in the aftermath. Rather than directing our attention towards controversies related to new and emerging technologies, which is often the case within participatory as well as speculative design, the projects explored how to un/make the harm of previous designs.

While both invitations were scientifically grounded, and were possible to try out in small scales, the proposals, to compost plastics and phytoremediate soil, were carried out to varying degrees.

While the invitation to compost plastic was doable for most participants, the invitation to remediate the soil through plants turned out to be more difficult to carry out fully. Some who showed great enthusiasm receiving the seeds never got around to plant them. Others who planted the seeds did not manage to get them growing. While we had several discussions with participants on the possibility of planting seeds in areas that we knew were polluted, the participants focused on planting seeds in their gardens with soil that the scanning sessions had shown to be healthy. The seeds were thus asked to do things other than clean polluted soil, such as being aesthetically pleasing and provide protein.

One reason for this difference between the two cases might be that the invitation to compost plastics required a much shorter engagement. Another reason might be that the process of composting plastics involved a much more immediate and visible transformation. Perhaps more importantly, the stakes of participating are clearly different. Several participants who took part in composting plastics expressed a general unease with having worms in their homes, but seemed to trust that the glass jar would make the worms stay put. And the risk of having the worms escape wasn't all too daunting. There were however unresolved ethical concerns regarding the worm's well-being, and critical questions regarding long-term effects of feeding the worms with plastics. However, none of the people who participated in composting plastics expressed any strong concerns regarding their own safety or other serious effects of doing the small-scale experiment. The uncertainties could somehow be negotiated within the setting of the project.

The invitation to remediate polluted soil through phytoremediation was different. In this case the stakes seemed to be higher for those who participated. They all lived in an area that is known for soil polluted by metals from the glass production. Some had taken part in studies regarding their health. Some had relatives that had suffered from getting high doses of metals into their bodies. To many of them the invitation to remediate the soil through plants seemed to involve too many risks, for themselves as well as other humans and non-humans, and raised questions such as: What if animals eat the plants? What to do with the plants when they have grown? Is the Lupin an invasive species?

Rather than opening up for imagination or speculations, the invitation seemed to open up for a wish for more knowledge on levels of metals; whether the soil was actually polluted or not. More specifically, there was an interest in getting to know more about the soil in their gardens and other places where the participants grow greens. As a response to this wish we hosted a soil scanning workshop that accompanied a yearly cleaning day. The other cleaning that was going on was immediate, such as raking leaves and picking up plastic containers. Cleaning soil from metals, that we were scanning for, would however be of a less doable sort. While it has not been explicitly expressed in these terms, the reluctance to plant seeds in clearly polluted areas, can be understood as an expression of hesitation regarding the assumption that these matters can be resolved. Perhaps it is more reasonable to find ways of living with them, which might involve knowing where you can plant greens and where you should be extra careful. A possible way of understanding the hesitation would be to see it as a development of situated knowledges that helps in navigating between cultivation of the known and unknown, the doable and the non-doable.

Taken together, the two different proposals to un/make matters, did not emerge as easy fixes or universal solutions to well defined problems. Instead it could be said that the invitations to put these proposals to work, in more or less doable ways, also participated in un/making them, or at least trouble them.

\section{Un/Making what?}

Having done these events, where we invited to combine speculation and participation, it is fair to ask: what was this good for? What do we need these speculations for? Within participatory design participation is often used to inform or influence future design, processes, services, systems or even policies - and to empower the users. In our case the speculations and proposals made by the participants have not been used to inform or influence a new design. Neither has the speculation been used in any implicit way to influence policy.

Instead, the events could be understood to have managed to create awareness regarding conditions of the aftermath, such as plastics waste and polluted soil. To some extent we would suggest that the events managed to do so, but that would also be a simplification. Rather than simply disseminating knowledge regarding a problem and solutions to that problem, our events aimed to enable speculations on the participants' entanglement in specific matters and how to 
continue to participate in these matters. In other words, we did not provide a well-defined problem or solution. This was up for negotiations in the events.

In some respects, this approach has much in common with inventive methods [27], which suggest that the method should allow for the problem, and perhaps also its potential solutions, to be questioned and altered. Michael [30] has suggested that speculative design has this potential, to enable inventive problem making. But instead of locating the inventive problem making to a designed object in a gallery, detached from everyday living, we invited for speculations to take place through the events and prototypes in the ongoing lives of the participants. The various responses and speculations made by participants ranged from the scientifically and culturally plausible to the fantastic, spectacular and impossible. By enabling speculations to be made by multiple actors, in multiple locations and situations, it has also become obvious that there isn't one singular preferred future, nor a singular past or present.

A potential critique towards this approach is that a lot of responsibility is placed on the individual, or the public. As the speculations show, individual action is often not sufficient to solve these issues. Change and impact will also be made through, for example, policies and designs. Therefore, we do not suggest that a combination of speculative and participatory design approaches should replace all other approaches. Matters in the aftermath, such as plastic waste or polluted soil, need to be un/made in multiple ways. As we have mentioned, one way of un/making can be done through offering alternatives to unsustainable practices or designs, which we did in Un/Making the Plastic Straw. The aftermath of what has already been made will however continue to matter. Exploring the practice of un/making in the aftermath is not only a matter of un/making harmful material relationships, but one of involving un/making progressivist imaginaries that have participated in generating the situation at hand. This might also involve un/making the assumption that all kinds of problems, such as microplastics in oceans or heavy metals in soil, can be solved once and for all. On a broader scale we hope that our work in the Un/Making Studio can participate in unmaking progressivist and anthropocentric imaginaries, in order to "make space" for a design practice that takes responsibility for its past and how it matters for what is yet to come.

As a final point, we would like to acknowledge that also practices of un/making can generate an unexpected and unwanted aftermath. The practice of un/making should thus be approached with some hesitation, and never be approached as a universal solution.

\section{ACKNOWLEDGEMENTS}

We would like to extend our heartfelt thank you to the participants who have answered to our different invitations to engage with un/making matters in the aftermath. We are grateful for the collaborations with the HYBRID MATTERs team, Li Jönsson, Louise Mazet, Alicia Smedberg, Laura Ferrans and Sina Shahabi Ghahfarokhi in the two different projects. Finally, we want to thank Daniela Rosner for her valuable input on this paper. The research has been financed by the Nordic Culture Fund and the Swedish Research Council.

\section{REFERENCES}

[1] Melanie Bergmann, Sophia Mützel, Sebastian Primpke, Mine B. Tekman, Jürg Trachsel, and Gunnar Gerdts. 2019. White and Wonderful? Microplastics Prevail in Snow from the Alps to the Arctic. Science Advances 5 (8): eaax1157. https://doi.org/10.1126/sciadv.aax1157.

[2] Thomas Binder, Eva Brandt, Pelle Ehn and Joachim Halse. 2015. Democratic design experiments: between parliament and laboratory. CoDesign: International Journal of CoCreation in Design and the Arts, 11, (34): 152-165.

[3] Rachel Clarke, Sara Heitlinger, Marcus Foth, Carl DiSalvo, Ann Light, and Laura Forlano. 2018. 'Morethan-Human Urban Futures: Speculative Participatory Design to Avoid Ecocidal Smart Cities'. In Proceedings of the 15th Participatory Design Conference: Short Papers, Situated Actions, Workshops and Tutorial - Volume 2, 34:1-34:4. PDC '18. New York, NY, USA: ACM. https://doi.org/10.1145/3210604.3210641.

[4] Gretchen Coombs, Andrew McNamara, and Gavin Sade. 2019. Undesign: Critical Practices at the Intersection of Art and Design. Milton: Routledge. http://ebookcentral.proquest.com/lib/malmo/detail.acti on?docID=5569064.

[5] Heather Davis. 2015. Life \& Death in the Anthropocene: A Short History of Plastic. In Art in the Anthropocene: Encounters Among Aesthetics, Politics, Environments and Epistemologies, edited by Etienne Turpin and Heather Davis, 347-58. London: Open Humanities Press. https://doi.org/10.26530/OAPEN_560010.

[6] Carl DiSalvo. 2016. The Irony of Drones for Foraging: Exploring the Work of Speculative Interventions. In Design Anthropological Futures: Exploring Emergence, Intervention and Formation, edited by Rachel Charlotte Smith, Kasper Tang Vangkilde, Mette Gislev Kjaersgaard, Ton Otto, Joachim Halse, and Thomas Binder, 139-54. London and New York: Bloomsbury Academic, an imprint of Bloomsbury Publishing, Plc.

[7] Anthony Dunne and Fiona Raby. 2013. Speculative Everything: Design, Fiction, and Social Dreaming. Cambridge, MA: The MIT Press.

[8] Giuseppe Feola. 2019. Degrowth and the Unmaking of Capitalism Beyond 'Decolonization of the 
Imaginary'. ACME: An International Journal for Critical Geographies 18 (4): 977-997.

[9] Marissa Fessenden. 2015. Notoriously Durable Styrofoam Could Be Munched by Mealworms. Smithsonian. 5 October 2015.

https://www.smithsonianmag.com/smartnews/notoriously-durable-styrofoam-could-bemunched-mealworms-180956817/.

[10] Tony Fry. 2009. Design Futuring: Sustainability, Ethics and New Practice. London and New York: Bloomsbury.

[11] Tony Fry. 2012. Becoming Human by Design. London: Bloomsbury.

[12] Jennifer Gabrys, Guy Hawkins, and Mike Michael, eds. 2013. Accumulation. The Material Politics of Plastic. London and New York: Routledge.

[13] Anne Galloway. 2013. Towards Fantastic Ethnography and Speculative Design. Ethnography Matters (blog). 17 September 2013. http://ethnographymatters.net/blog/2013/09/17/toward s-fantastic-ethnography-and-speculative-design/.

[14] Anne Galloway and Catherine Caudwell. 2019. Speculative Design as Research Method. From Answers to Questions and "Staying with the Trouble". In Undesign: A Critical Practice at the Intersection of Art and Design., edited by Gretchen Coombs, Andrew McNamara, and Gavin Sade. Milton: Routledge.

[15] Alix Gerber. 2018. Participatory Speculation: Futures of Public Safety. In Proceedings of the 15th Participatory Design Conference: Short Papers, Situated Actions, Workshops and Tutorial - Volume 2, 23:1-23:4. PDC '18. New York, NY, USA: ACM. https://doi.org/10.1145/3210604.3210640.

[16] Mary Beth Griggs. 2015. Mealworms Can Happily And Safely Eat Styrofoam. Popular Science. 30 September 2015.

https://www.popsci.com/mealworms-can-safelydevour-plastics.

[17] Karin Hansson, Jaz Hee-jeong Choi, Tessy Cerratto Pargman, Shaowen Bardzell, Laura Forlano, Carl DiSalvo, Silvia Lindtner, and Somya Joshi. 2016. Ting: Making Publics Through Provocation, Conflict and Appropriation. In Proceedings of the 14th Participatory Design Conference: Short Papers, Interactive Exhibitions, Workshops - Volume 2, 109110. PDC '16. New York, NY, USA: ACM. https://doi.org/10.1145/2948076.2948092.

[18] Jareen Imam. 2016. Styrofoam-Eating Mealworms Might Help Reduce Plastic Waste, Study Finds. CNN. 21 July 2016. https://www.cnn.com/2015/09/30/us/styrofoameating-mealworms-plastic-waste/index.html.
[19] Steven J. Jackson. 2014. Rethinking Repair. In Media Technologies: Essays on Communication, Materiality and Society, edited by Tarleton Gillespie, Pablo J.

Boczkowski, and Kirsten A. Foot, 221-40. Cambridge, MA: The MIT Press. https://doi.org/10.7551/mitpress/9780262525374.003. 0011.

[20] Sirin Kale. 2019. The Rise of "Ungardening": How to Turn a Backyard into a Wildlife Haven'. The Guardian, 5 August 2019, sec. News. https://www.theguardian.com/news/shortcuts/2019/au $\mathrm{g} / 05 /$ garden-wildlife-haven-rewilding-ungardeningpond.

[21] Kate Kennen and Niall Kirkwood. 2015. Phyto: Principles and Resources for Site Remediation and Landscape Design. First edition. New York: Routledge.

[22] Tobie Kerridge. 2016. Designing Debate: The Entanglement of Speculative Design and Upstream Engagement. In Proceedings of DRS 2016, 1-12. Brighton, UK.

[23] John Law. 2004. After Method - Mess in Social Science Research. London and New York: Routledge.

[24] Max Liboiron. 2016. Redefining Pollution and Action: The Matter of Plastics. Journal of Material Culture 21 (1): 87-110. https://doi.org/10.1177/1359183515622966.

[25] Kristina Lindström and Åsa Ståhl. 2016. Becoming response-able stakeholders - participatory design in times of uncertainties. In Proceedings of the 14th Participatory Design Conference: Short Papers, Interactive Exhibitions, Workshops - Volume 2, 4144. PDC '16. New York, NY, USA: ACM https://doi.org/10.1145/2948076.2948086

[26] Kristina Lindström and Åsa Ståhl. 2019. Caring design experiments in the aftermath. In Proceedings of the 8th Bi-Annual Nordic Design Research Society Conference - Who Cares?, 1-9. Finland. https://archive.nordes.org/index.php/n13/article/view/ 49

[27] Celia Lury and Nina Wakeford, eds. 2012. Inventive Methods. London: Routledge.

[28] Matt Malpass. 2013. Between Wit and Reason: Defining Associative, Speculative, and Critical Design in Practice. Design and Culture 5 (3): 333-56. https://doi.org/10.2752/175470813X13705953612200.

[29] Andrew McNamara, Gretchen Coombs, and Gavin Sade. 2019. Introduction. In Undesign: A Critical Practice at the Intersection of Art and Design., edited by Gretchen Coombs, Andrew McNamara, and Gavin Sade. Milton, UNITED KINGDOM: Routledge.

[30] Mike Michael. 2012. "What Are We Busy Doing?": Engaging the Idiot. Science, Technology, \& Human 
Values 37 (5): 528-54.

https://doi.org/10.1177/0162243911428624.

[31] Luiza Prado and Pedro Oliviera. 2017. Questioning the "Critical" in Speculative \& Critical Design. Medium. 31 August 2017. https://medium.com/aparede/questioning-the-critical-in-speculative-criticaldesign-5a355cac2ca4.

[32] Søren Rosenbak. 2018. Designing for a City of Lies: How to Rethink Belgiums Smartest City Through Engaging the Imaginaries of Its Local Citizens. In Proceedings of the 15th Participatory Design Conference: Short Papers, Situated Actions, Workshops and Tutorial - Volume 2, 38:1-38:3. PDC '18. New York, NY, USA: ACM. https://doi.org/10.1145/3210604.3214363.

[33] Marco C. Rozendaal, Marie L. Heidingsfelder, and Frank Kupper. 2016. Exploring Embodied Speculation in Participatory Design and Innovation. In Proceedings of the 14th Participatory Design Conference: Short Papers, Interactive Exhibitions, Workshops - Volume 2, 100-102. PDC '16. New York, NY, USA: ACM. https://doi.org/10.1145/2948076.2948102.

[34] Elizabeth Shove. 2012. The Shadowy Side of Innovation: Unmaking and Sustainability. Technology Analysis \& Strategic Management 24 (4): 363-75. https://doi.org/10.1080/09537325.2012.663961.

[35] Herbert Simon. 1996. The Sciences of the Artificial. Boston: MIT Press.

[36] Therese Thomasson. 2010. Max 5,5 Kilo Grönsaker Ur Egen Odling. Sydsvenskan. Accessed 10 September 2018. https://www.sydsvenskan.se/201006-28/max-55-kilo-gronsaker-ur-egen-odling.

[37] Martín Tironi. 2018. Speculative Prototyping, Frictions and Counter-Participation: A Civic Intervention with Homeless Individuals. Design Studies 59 (November): 117-38. https://doi.org/10.1016/j.destud.2018.05.003.

[38] Cameron Tonkinwise. 2014. How We Intend to Future: Review of Anthony Dunne and Fiona Raby, Speculative Everything: Design, Fiction, and Social Dreaming'. Design Philosophy Papers 12 (2): 169-87. https://doi.org/10.2752/144871314X14159818597676.

[39] Cameron Tonkinwise. 2014. Design Away. In Design as Future-Making, edited by Susan Yelavich and Barbara Adams. London: Bloomsbury.

[40] Cameron Tonkinwise. 2019. "I Prefer No to" AntiProgressive Designing. In Undesign: A Critical Practice at the Intersection of Art and Design., edited by Gretchen Coombs, Andrew McNamara, and Gavin Sade. Milton, UNITED KINGDOM: Routledge.

[41] 'Unmaking: A Research Programme'. n.d. UNMAKING: A Research Programme on the
Disruption of Capitalism in Societal Transformation to Sustainability. Accessed 27 August 2019. https://unmaking.sites.uu.nl/about/.

[42] Dongqi Yang, Huahong Shi, Lan Li, Jiana Li, Khalida Jabeen, and Prabhu Kolandhasamy. 2015. Microplastic Pollution in Table Salts from China. Environmental Science \& Technology 49 (22): 1362227. https://doi.org/10.1021/acs.est.5b03163.

[43] Yu Yang, Jun Yang, Wei-Min Wu, Jiao Zhao, Yiling Song, Longcheng Gao, Ruifu Yang, and Lei Jiang. 2015. Biodegradation and Mineralization of Polystyrene by Plastic-Eating Mealworms: Part 1 . Chemical and Physical Characterization and Isotopic Tests. Environmental Science \& Technology 49 (20): 12080-86. https://doi.org/10.1021/acs.est.5b02661. 